Review

\title{
"Evolution" of Embryogenesis: Complexity of the Early Developmental Stages in the Animal Kingdom
}

Steve Liebich ${ }^{1,2, *}$

Founder \& CEO at Babu ${ }^{\mathrm{TM}}$ (BabuBio LLC), Potsdam, New York, USA; E-Mail: liebicsf@clarkson.edu

* Correspondence: Steve Liebich; E-Mail: liebicsf@clarkson.edu

Academic Editor: Joep Geraedts

OBM Genetics

2020, volume 4, issue 3

doi:10.21926/obm.genet.2003113
Received: March 16, 2020

Accepted: June 27, 2020

Published: July 02, 2020

\begin{abstract}
Multicellularity has gained the advantage over the unicellular world by expanding the number of increasingly more complex tissues that achieve advanced and specific functions. This same event gave rise to the most evolved group of organisms, namely mammals. Even though the complexity of multicellular organisms does not necessarily provide them with excellent adaptation modes performed by unicellular and prokaryotic organisms, this complexity per se stands as one of the greatest phenomena in biology. However, there is an inherent set of biochemical and physiological programs that all animals share and tend to execute in similar manners. Most of these processes are evolutionarily conserved and often arise several times with different phylogenetic origins; this implies their importance and universalism in the Animal kingdom. This review summarizes the most significant embryological mechanisms described in many model organisms of echinoderms, nematodes, insects, chordates, and mammals including humans. Although complex and diverse, most of the mechanisms share an outstanding number of similarities that lead researchers to find the answer as to how and in which way the mechanisms had succeeded to help develop complex life.
\end{abstract}

\section{Keywords}

Developmental biology; molecular embryology; gene regulatory network; developmental fields; cellular differentiation

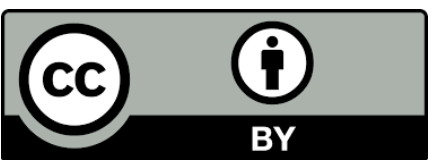

(C) 2020 by the author. This is an open access article distributed under the conditions of the Creative Commons by Attribution License, which permits unrestricted use, distribution, and reproduction in any medium or format, provided the original work is correctly cited. 


\section{Introduction}

Developmental biology started its existence with August Weismann's discovery of germ cells being the hereditary agents in all multicellular eukaryotes. Later, the field gained momentum with the experiments of Wilhelm Roux, Hans Driesch, and Thomas Morgan in the late $19^{\text {th }}$ century. It was not until the second half of the $20^{\text {th }}$ century when molecular bases had replaced their theoretical stands. With the discovery of DNA and the launch of genomics, new horizons appeared [1].

Processes of independent distribution of chromosomes [2], transcription factors networking and cooperativity [3-5], morphogens activity [6-8], and establishing embryonic cues with different competence and fates $[9,10]$ are now better understood and pinned to the enhancing field of molecular embryology and developmental biology. Today, we know much about intercellular communication, cellular signaling, and external molecular cues affecting the developing embryo with downstream effects leading to genomic reprogramming and developmental determinants distribution. The recent research in the cross-talk between developmental biology and other molecular fields has helped establish correlation between cellular differentiation, growth, and senescence which gives insight into cancerogenesis, bodily ageing, and congenital disorders. And yet, the mechanisms of fertilization, embryonic nuclear organization, zygotic genome restart, cellular differentiation, and the embryonic (developmental) fields formation still remain recondite.

At what stage does the first process of cellular specification and competence start? Which mechanisms are responsible for the first cue of differentiation, axes formation, tissue organizers, and direction of growth and development? Do these processes differ among different phyla in the Animal kingdom? If so, to what degree do they differ? Does a common denominator of early development exist? These questions remain unanswered, although the recent advancement in developmental biology and related fields brings us closer to the better understanding of the complexity of embryogenesis.

This review focuses on biomolecular mechanisms of the early embryo development stages presented on the examples of seven different metazoans. The last chapter shifts the focus onto humans with similarities and differences in embryological events compared to other animals. Surprisingly, these are discrete genomic differences found in the agents of embryogenesis that play the major role in defining the supreme developmental process of humans over the rest of animals.

\section{Fertilization and Cleavage}

The $C$. elegans or $D$. rero embryos are optically transparent which facilitates their examination; similarly, sea urchin's fertilization takes place in water and proper laboratory conditions can be set up to follow the mechanism. Fertilization in higher vertebrates is more difficult to follow, since the process takes place inside the female's reproductive tract and the imaging techniques require a more advanced and skilled approach. However, even though the specific steps of fertilization and the cleavage divisions vary among different animals, the preliminary course of action remains very much alike. 
During insemination, the chemoattraction mechanisms facilitate the sperm's entry into the egg [11]. In sea urchins, resact was isolated from the egg's vitelline layer as a chemoattractant for sperm [12]. Bindin was isolated as an insoluble protein on the sperm's acrosome vesicle that binds ERB1 on the egg and facilitates the acrosome reaction [13, 14]. In mammals, a number of molecules from sperm have been recognized to act as chemoattraction substances, e.g. Sp56 (acrosomal matrix glycoprotein), galactosyltransferase and the ADAM (a disintegrin and metalloproteinase) family, which interact with the egg's zona pellucida markers, especially ZP1 [15, 16].

Once the sperm enters the egg, the two pronuclei (condensed haploid chromatin) fuse and form the zygote. The exact mechanism of cortical (egg) and acrosomal (sperm) reactions and the pronuclei fusion differ among animals, but the fundamental principles remain the same; including in humans [17-19]. As shown in their elegant experiment, McCulloh and Chambers (1992) reputed that electrophysiological changes during the gametes fusion can lead to speculative sperm receptor kinases and the PLC $Y$ activation, followed by the intracellular $\mathrm{IP}_{3}$-driven signaling cascade [20]. Calcium ions play a central role in fertilization by activating a plethora of calcium-dependent intracellular signals, which mediate further rearrangements and early zygote processes, including microtubules nucleation, centrosomes and mitotic spindle positioning, chromatin remodeling, and cytoskeleton rearrangements [21-24]. These processes precede the next major event of embryo development, the cleavage.

Embryo cleavage is defined as the first rounds of cellular division with little to no growth of the dividing cells. This brings the blastula stage, where an embryo solely consists of equally sized blastomeres (the focus is shifted to producing new genetic material necessary for further specification stages). Either through the early genome activation (Xenopus, zebrafish) or maternal mRNA transcripts (mouse, human), the embryo depends on newly synthesized proteins that are essential in cleavage initiation [25-27]. Based on this process, animal embryos can be divided into two groups: the autologous embryos (depending on the maternal mRNA transcripts) and the conditional embryos (depending mostly on their own genome activation). Cyclins, cyclindependent kinases (cdk), and microtubules, among others, contribute to the mitotic spindle formation which divides each blastomere perpendicularly to the center position of the nucleus (Hartwig's rule). Blastomeres divide into identical daughter cells with a cleavage furrow cutting the previous cell at the right angle (Sach's rule). The rate of cleavage (and the pace of embryo development) is inversely proportional to the amount of yolk in the egg (Balfour's rule).

Classification of embryos can also be based on their cleavage type. In holoblastic cleavage, the whole zygote is completely dichotomized with the evenly deposited yolk. In meroblastic cleavage, the egg is divided incompletely with a portion of the yolk always remaining (Figure 1). According to Collazo et al., meroblastic cleavage appears to have arisen independently five times in different phyla, while holoblastic cleavage is a relatively new evolutionary tool occurring in more developed organisms [28]. Apart from the cleavage types, most animals exhibit a similar pattern of the first cellular division: first division at a longitudinal plane, another one at the angle of 90 degrees to the plane of the first, and the third division being perpendicular to the first two [29]. In echinoderms, the first two divisions are meridional, the third is equatorial, and the consecutive ones are either meridional or equatorial. In tunicates, the first two divisions are meridional. In nematodes, the first division is meridional, whereas the second is either equatorial (for AB cell) or meridional (for 
P1 cell). In mammals, the first division is meridional and the second division can be either meridional or equatorial [29].

a)

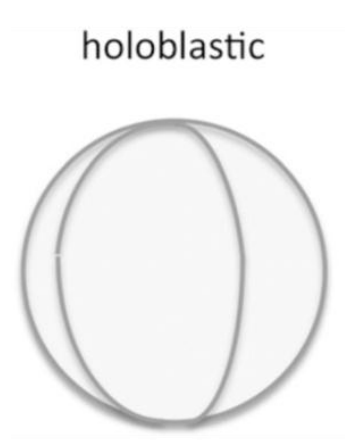

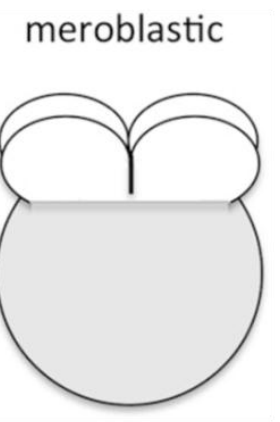

b)

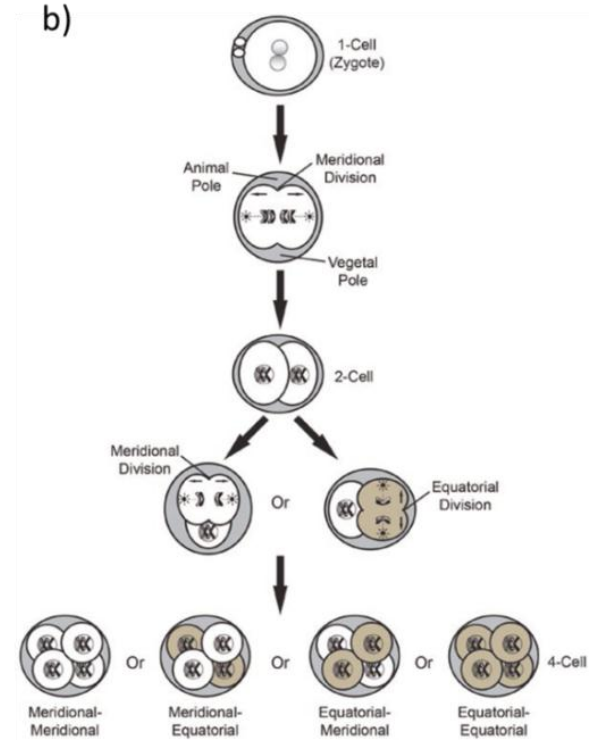

Figure 1 Cleavage types and holoblastic rotational cleavage of mammals. (a) Cleavage in animals is characterized as either holoblastic or meroblastic. In holoblastic cleavage, the yolk content is distributed evenly (equal cleavage) to every daughter cell or the distribution becomes uneven (unequal distribution) with the first division being usually along meridional plane. The yolk content remains intact at the vegetal pole of the egg, so that only blastomeres of the animal pole of the dividing embryo encompass the cleavage site. (b) Mammals represent the holoblastic (equal) rotational cleavage, where the upper tier of cells arrange rotationally over the bottom tier of embryo cells. The first division is meridional (M) and the second division is either meridional (M) or equatorial (E). It has been shown that variants $M M$ or $E E$ have more chances to survive because of even distribution of maternal constituents. Adapted from [29].

It is still uncertain as to how the axis of cleavage is determined by the zygote and its daughter cells. One hypothesis posits that the first division proceeds in an axis perpendicular to the main mass center of the cell [30]. Another one presumes the early fate constituents (autologous embryo type) determining the polarity axis along which the mitotic spindle is formed [31]. For instance, in $C$. elegans, the PAR-6/PAR-3/PKC-3 and PAR-2/PAR-1 complexes establish the primordial anterior-posterior axis along which the division takes place [32]. The question of the primordial cleavage axis in mammals has not yet been answered. Piotrowska and Zernicka-Goetz (2001) posited that the primordial embryo axis is formed and aided after fertilization provoked by the sperm's entry into the egg [33]. Gardner and Davies (2003) pointed out that the animalvegetal axis of the zygote must be specified before fertilization [34]. Hiiragi and Solter (2004) performed a series of elegant experiments by removing either maternal or parental pronuclei from the gametes and showed that the primary axis in the mouse egg is not predetermined, but established by the spatial arrangement of the two opposing pronuclei [35]. Thus, the primordial cleavage axis in mammalian embryos is determined through the mechanisms triggered by fertilization. 


\section{The Early Genome Activation}

In animals, maternal transcripts generated by the oocyte control the earliest zygotic developmental processes; with time, the quiescent zygotic genome becomes activated and the maternal determinants clear, which is known in the literature as the maternal-to-zygotic transition (MZT). During the MZT, an embryo becomes independent from maternal products and activates its own mRNA synthesis. Another term, the zygotic genome activation (ZGA) refers to the second event of the MZT which is the zygote's genome activation; although different organisms exhibit their genome expression at miscellaneous cell cycles, hence the most preferable term is the early genome activation (EGA). The MZT and EGA are very much conserved in all animals, therefore it is essential to recognize the species-specific developmental programs employed by different organisms [36].

In fast-developing vertebrates (almost all anamniotes), embryos are characterized by expeditious cell divisions following fertilization, lately occurring MZT, and accelerated growth; slow-developing amniotes are marked by much slower embryonic development and the early MZT [37] (Figure 2). In Xenopus, zebrafish, and Drosophila (anamniotes), the maternal factors (mostly the oocyte's mRNA molecules, including mi-RNA and piwi-RNA) are sufficient to guide the first cells through the earliest biological development [38-42]. In amniotes (including mammals), where the dependence on maternal constituents has not been objectively defined, many signaling molecules activate the zygotic genome (whose first products maintain the blastomeres homeostasis), regulate the chromatin permissiveness and its protein content, and control the cell cycle $[43,44]$. Levels of early accessible transcription factors are also tightly regulated through miscellaneous mechanisms which include sequestration and phosphorylation $[45,46]$, trans-acting inhibitory factors [47], specialized promoters transactivation [48], and switching from TATAcontaining to TATA-less promoter activation $[49,50]$.

The embryo genome is activated stepwise or by the so-called waves. The waves of newly transcribed genes appear because the early genes may be deleterious at the later stages for the embryo development, and thus the complex transcription machinery must decide of singular gene permissiveness timing as well as the spatial determination [51]. There are three possibilities of how the waves occur in the early embryos: clock-like zygote's genome activation (gene cluster $A$, then gene cluster $B$, etc.), cell count-dependent mechanism (a number of blastomeres impose the chromatin remodeling), and stepwise cycling (maternal factors trigger the EGA, which leads to further cellular growth and specialization) [51].

Researchers share different ideas on which mechanisms are critical for the embryo to switch from maternal to its own genome activity. Maternal factors may deposit in the dividing cells and initiate the "domino effect" for singular loci activation if the threshold for the maternal factors concentration is reached [36]. Also, the nuclear to cytoplasmic ratio ( $\mathrm{N}: \mathrm{C}$ ) plays a significant role in the EGA [52]; with every cell division, 2- fold decrease of cytoplasm volume leads to doubling the $\mathrm{N}: \mathrm{C}$ ratio, which might lead to the maternal mRNA transcripts titration, including the proteins involved in the ZGA inhibition [53]. Similarly to this hypothesis, another one proposes that free histones and transcription factors compete for specific genes loci, and that reducing the histones concentration by increasing the $\mathrm{N}: \mathrm{C}$ ratio advances the transcription onset of the particular genes that had been repressed prior to the embryo cells cleavage [54]. 
Multiple genes have been correlated with the EGA in animals and their relatedness to the underlying molecular processes in the blastomeres have been recognized. For instance, in zebrafish Nanog, SoxB1, and Pouf5f3 (mammalian Oct4 homolog) are critical to initiate approx.75\% of the first ZGA stage genes transcription [55]. In mammals, Nanog, Oct4, TIF1 $\alpha$, DUX, and HERVL (endogenous retroviral element) support the early (2-, 4-, and 8-cell stage) embryo genome activation [56, 57]. Understanding how the MZT is initiated, maintained, and controlled over the early course of embryogenesis is essential to understanding the developmental cues of embryogenesis.

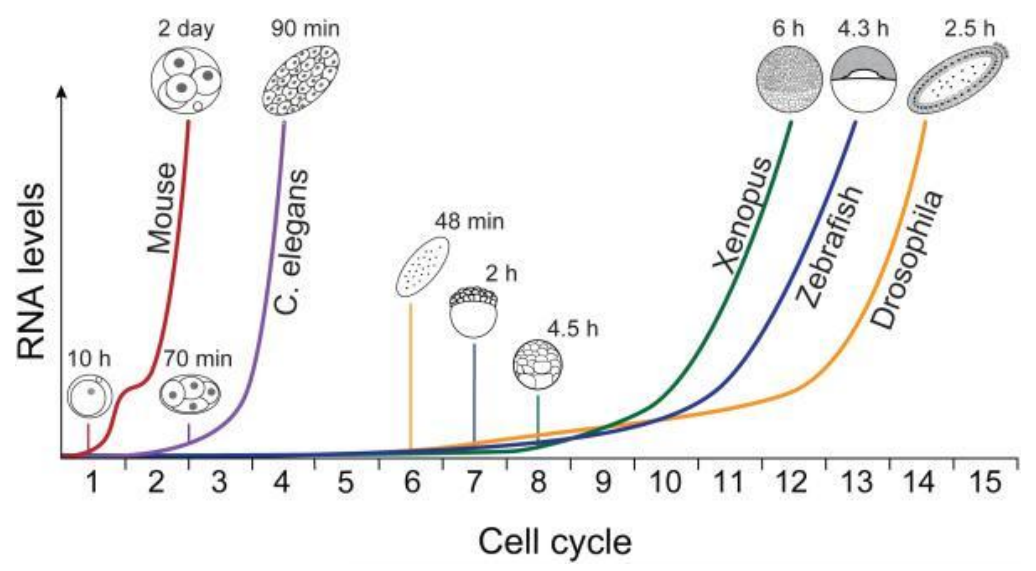

Figure 2 Timing of increase in the cytosolic mRNA level transcripts in different model organisms. The EGA is one of the two most relevant events of the maternal-to-zygotic (MZT) episode in most animals. Fast-developing animals express their own genetic material after many completed cell cycles (rapid growth - late MZT), whereas slowdeveloping animals usually do not depend on any maternal effect and hence activate their genome after 1-2 first cleavage divisions (slow growth - early MZT). Notice that the fast and slow development refers to the time interval between subsequent cell cycles in developing animal embryo. Mouse is an example of slow-developing animal; nematodes, amphibians, fish, and arthropods represent fast-developing animals. Adapted from [36].

\section{Maternal Effect}

The maternal effect is responsible for the autonomous embryonic specification through the early oocyte mRNA transcripts not depending on the EGA. This embryonic effect is mainly observed in the fast-developing animals that depend on the maternal factors synthesized in the egg. Maternal mRNA transcripts, depending on the species, control meiotic egg maturation, early anterior/posterior $(A / P)$, dorsal-ventral $(D / V)$, and left-right $(L / R)$ axes formation, the germ cells region and lineage development, and gastrulation fate causes establishment $[58,59]$. These prefertilization egg's cues containing maternal mRNA transcripts in different gradients found in different cell's compartments contribute to the phenomenon called the maternal anisotropy [76].

For instance, Bicoid and Nanos are the abundant axes and segmentation determinants in Drosophila (Table 1). During early developmental stages, bicoid and nanos primordial mRNA transcripts are transported to the anterior and posterior egg poles, respectively [60,61]; Bicoid represses the caudal mRNA transcripts (Nanos, Caudal, Oskar) in the anterior pole establishing the 
$A / P$ axis of the oocyte [62]. Bicoid also enhances the anterior gap genes, whose varying concentrations lead to the pair-rule genes expression which establish the $A / P$ axis perpendicular to periodic band units [62]. Another example of the maternal effect is the Balbiani body found in many vertebrates. The Balbiani body is a transient collection of organelles, inclusions, and molecules that assemble adjacent to the nucleus of primary oocytes [63]. Dosch et al. discovered that zebrafish' Bucky ball mediates the Balbiani body localization in the vegetal pole of the oocyte and thus overrides the default animal pole establishing the earliest A/P axis [64].

Table 1 Diversity in the onset and execution of developmental programs in Animalia.

\begin{tabular}{|c|c|c|c|c|c|c|}
\hline Organism & $\begin{array}{c}\text { Development } \\
\text { type }\end{array}$ & $\begin{array}{c}\text { EGA } \\
\text { timing }\end{array}$ & $\begin{array}{c}\text { Cleavage } \\
\text { type } \\
\text { established in } \\
\text { the oocyte }\end{array}$ & $\begin{array}{c}\text { Eutonomously } \\
\text { specified } \\
\text { cell lineages }\end{array}$ & Maternal effect \\
\hline $\begin{array}{c}\text { Sea urchin } \\
\text { (echinoderms) }\end{array}$ & Slow & $18-22 \mathrm{~h}$ & $\begin{array}{c}\text { Holoblastic } \\
\text { radial }\end{array}$ & An/Vg & Mesenchyme & $\begin{array}{c}\text { B-catenin/Tcf, } \\
\text { Otx }\end{array}$ \\
\hline $\begin{array}{c}\text { C. } \text { elegans } \\
\text { (nematodes) }\end{array}$ & Fast & $90 \mathrm{~min}$ & $\begin{array}{c}\text { Holoblastic } \\
\text { rotational }\end{array}$ & $\mathrm{A} / \mathrm{P}$ & $\begin{array}{c}\text { Mesenchyme, } \\
\text { germ line, gut }\end{array}$ & PAR-6, PAR-3 \\
\hline $\begin{array}{c}\text { Drosophila } \\
\text { (arthropods) }\end{array}$ & Fast & $2.5 \mathrm{~h}$ & $\begin{array}{c}\text { Meroblastic } \\
\text { superficial }\end{array}$ & $\mathrm{A} / \mathrm{P}, \mathrm{D} / \mathrm{V}$ & $\begin{array}{c}\text { Pole cells, major } \\
\text { pattern } \\
\text { segments }\end{array}$ & $\begin{array}{c}\text { Bicoid, Nanos, } \\
\text { Caudal }\end{array}$ \\
\hline $\begin{array}{c}\text { Zebrafish } \\
\text { (chordates) }\end{array}$ & Fast & $4.3 \mathrm{~h}$ & $\begin{array}{c}\text { Meroblastic } \\
\text { discoidal }\end{array}$ & $\mathrm{An} / \mathrm{Vg}$ & $\begin{array}{c}\text { radar, yobo, } \\
\text { janus, foxH1 }\end{array}$ \\
\hline $\begin{array}{c}\text { Xenopus } \\
\text { (chordates) }\end{array}$ & Fast & $6 \mathrm{~h}$ & $\begin{array}{c}\text { Holoblastic } \\
\text { radial }\end{array}$ & $\mathrm{An} / \mathrm{Vg}$ & $\begin{array}{c}\text { Gut endoderm, } \\
\text { ciliated } \\
\text { ectoderm }\end{array}$ & $\begin{array}{c}\text { XegT, } \\
\text { Xbrachyury, } \\
\text { Antipodean }\end{array}$ \\
\hline $\begin{array}{c}\text { Mus } \\
\text { (mammals) }\end{array}$ & Slow & $1-2 \mathrm{~d}$ & $\begin{array}{c}\text { Holoblastic } \\
\text { rotational }\end{array}$ & --- & $\begin{array}{c}\text { DICER1, Ago2, } \\
\text { HR6A, Zar1 }\end{array}$ \\
\hline $\begin{array}{c}\text { Human } \\
\text { (mammals) }\end{array}$ & Slow & $4-8 \mathrm{~d}$ & $\begin{array}{c}\text { Holoblastic } \\
\text { rotational }\end{array}$ & --- & --- & Mater, ZAR1 \\
\hline
\end{tabular}

According to Davidson et al. [10], there are three types of embryos. Type 1 (echinodermates, nematodes) represents all metazoans expect for arthropods and vertebrates with both autonomous and conditional specification, rapid development, and lineage-specific activation of gene batteries. Type 2 (chordates, mammals) embryos encompass all vertebrates which are characterized by mostly conditional specification, slow or fast cleavage rate, and late embryo axis formation with early regional body plan execution. Type 3 refers to Arthropoda that exhibit the very unique cellularization process (cellular division with no plasma membrane formation) synchronous with rapid cleavage and prespecification of $A / P$ and $D / V$ axes in the egg. Cleavage in mammals is symmetrical and there is no experimentally determined early axis formation until the blastocyst stage (128-cell stage) which coalesces with their only conditional (indeterminate) specification; even though the maternal effect is majorly found in animals with autonomous specification, it has been show that maternal transcripts can be used by the egg and the early embryo in more contextual framework (see the text). ${ }^{1}$ animal/vegetal axis.

It has been commonly regarded that the maternal control does not occur in slow-developing 
animals, especially in vertebrates [65]; however, recent results have proven the notion wrong [6570]. Among others, Zernicka-Goetz \& Piotrowska and Gardner \& Davies have shown that the dorsal-ventral axis formation in the mouse embryo relies on the maternal gene products [71, 72]. Since then, a great number of studies have shown that the maternal effect does indeed take place in mammals as well [70, 73-75].

\section{Signaling Pathways}

The cell's ability to receive and respond to both extracellular and intracellular signaling molecules decides about its survival and functionality. Signaling pathways are indispensable for interblastomeric communication, placenta-embryo cross-talk, and navigation of the molecular events inside the embryo cells. Dozens of signaling pathways have been described in literature, but some of the most critical are FGF, Notch, Hedgehog, Src, EGFR, BMP, and Wnt. Responding to hormones and morphogens in different concentrations, a signaling pathway may activate or repress the same gene or a group of genes and interact with each other stimulating and modeling the signal. A great deal of signaling molecules also act as the short- and long-range morphogens, including hedgehog ligands in limb formation [77], Wingless proteins in body patterning [78], and the TGF- $\beta$ pathways in establishing the imaginal discs in insects [79].

A description of all or even a portion of the signaling pathways engaged in the embryo morphogenesis in animals exceeds the scope of this review. However, it will expand on the significance of extracellular signaling in the example of the peculiar Hedgehog signaling pathway (Figure 3).

Hedgehog proteins are conserved across a plethora of animals, especially the Hedgehog ligand whose Hedge domain is represented in protozoa and metazoa [80]. Starting from choanoflagellates, to sponges, to cnidarians, to mammals, Hedgehog directs the primordial body patterning and tissue development [81]. By its unusual covalent coupling of cholesterol at the Cterminus and the $\mathrm{N}$-terminal palmitoylation, and the conserved nature in most Bilateria, Hedgehog and other proteins related to the pathway seem to be at the odds with other signaling pathways [82].

The Hedgehog signaling has been extensively studied in Drosophila melanogaster, from which it had first been cloned [83]. Therefore, the following signal transduction pathway is based on the comprehensive analysis of the flies' mutations of the pathway's core components that are, in most cases, shared among vertebrates and invertebrates [80].

Located intracellularly, the Hedgehog signaling complex (HSC), composed of a few serine/threonine kinases, including protein kinase A (PKA) and glycogen synthase kinase 3 (GSK3). Phosphorylate Cubitus interruptus $(\mathrm{Cl})$, which is further truncated to its repressor form $(\mathrm{Cl}-\mathrm{R})$ that moves to the nucleus and inhibits the set of genes that Hedgehog signaling controls [84, 85]. In the absence of Hedgehog, its transporter-like receptor, Patched, inhibits a $\mathrm{G}$ protein-coupled receptor (GPCR) family member, Smoothened (SMO) [86]. However, if the Hedgehog protein (ligand) binds Patched, SMO is released from inhibition and becomes phosphorylated by the kinases of the HSC. Once phosphorylated, SMO interacts with Costal 2 (COS2) and helps it become phosphorylated; phosphorylation of $\mathrm{COS} 2$ releases $\mathrm{Cl}$ from the $\mathrm{HSC}[87,88]$. The full-length $\mathrm{Cl}(\mathrm{Cl}-\mathrm{FL})$ migrates to the nucleus, but unlike its suppressor variant, it interacts with a vast array of genes by activating 
their transcription [89]. The homologs to Drosophila's $\mathrm{Cl}$ proteins in vertebrates are GLI proteins (GLI1, GLI2, GLI3), which are the downstream effectors of the Hedgehog signaling [90].

In mammals, three isoforms of Hedgehog exist: Sonic hedgehog (Shh), Indian hedgehog (Ihh), and Desert hedgehog (Dhh) [91]. Shh is involved in the notochord, neural tube, and limb formation [92]; Ihh signals in the embryonic bone and cartilage tissues [43], whereas Dhh is mainly active at the sites of the germ cell line development and peripheral nerves [94]. Although it must be remembered that the same signaling pathway can be present in multiple sites of the developing embryo demonstrating miscellaneous and very often contradicting functions in cell growth and tissue formation. More so, signaling pathways, such as Hedgehog, intertwine with many other signaling molecules and morphogens developing the molecular framework of activation and inhibition signals commanding the transcription changes in the given sets of genes.
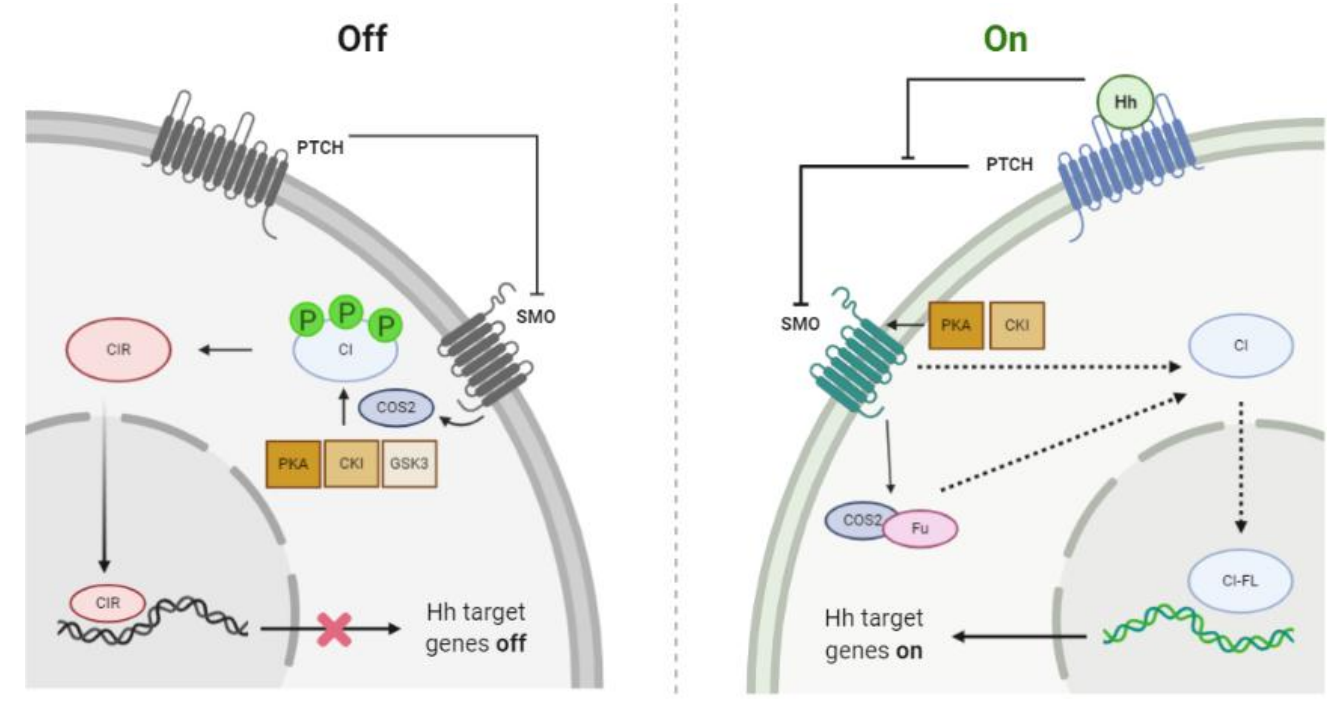

Figure 3 Hedgehog signaling pathway in Drosophila melanogaster. Hedgehog signaling portrays classical "on/off"' signaling pathway mode. In the absence of Hedgehog ligand (on the left), Patched (PTCH) inhibits Smoothed (SMO); the lack of SMO activity allows the Hedgehog signaling complex (HSC) kinases phosphorylate Slimb which mediates proteasome proteolysis of $\mathrm{Cl}$ to its truncated repressor form, $\mathrm{CIR}$. CIR is translocated to the nucleus and inhibits expression of all genes controlled by the Hedgehog signaling. Once Hh binds PTCH, inhibition of SMO is ceased, which becomes phosphorylated by PKA and CKI. Phosphorylated SMO recruits the COS2-Fused complex (Fused (Fu) is a Ser/Thr kinase) which otherwise would phosphorylate $\mathrm{Cl}$. Dissociated $\mathrm{Cl}-\mathrm{COS} 2$ complex frees $\mathrm{Cl}$ and its full-length variant moves to the nucleus and activates the downstream Hedgehog-dependent genes.

\section{Transcription Factors}

These transcription changes are modulated by trans-acting molecules, transcription factors. Transcription factors (TFs) act as molecular switches turning the genes on or off and manipulating the genomic identity of specific tissue. In the developing embryo, morphogens and signaling pathways work together to act downstream on specific transcription factors whose DNA binding sites enable them to activate and/or deactivate a set of genes responsible for explicit functions of 
the cell. TFs have binding sites for other proteins, too, and by reciprocal interactions they establish complex circuits that can be regulated and acted upon by signaling pathways, growth factors, mitogens, intercellular communication and environment sensing [95-97].

Transcription factors bind to or nearby the transcription start site (TSS) in the gene's promoter, where they regulate formation of the preinitiation complex (PIC) (the "core" PIC is composed of RNA polymerase II and the six transcription factors $(A, B, D, E, F, H)$ ) tethering to the consensus DNA cis- regulatory sequence, a TATA box [98]. The PIC factors control transcription of genes by regulating RNA polymerase engagement, its movement downstream the gene sequence, and the pace of mRNA polymerization; these proteins are conserved among different clades of animals and they are non-specific. However, if the promoter is activated by specific transcription factors with distinct binding sites at their domains, they can control spatial and temporal expression patterns of their target genes. Many transcription factors act upon the cis-regulatory elements (CRE) of a gene, such as enhancers, silencers, and insulators (distal regulation) to modulate the gene activity through chromatin remodeling, long-range looping, and non-coding RNA molecules [99-101]. CREs are the final target sites of often complex gene regulatory networks comprised of multiple functional motifs acting as genomic logical input gates, such as multi-input motif (MIM), dense overlapping region (DOR), or single-input motif (SIM) [98]. These high-leveled regulatory networks are especially present during the early gastrulation stages when the first progenitor fields and germ layer borders are established.

The large-scale meta-analysis of 119 transcription factors of 5 human cell lines were analyzed for their genome-wide binding profiles and hierarchy structure in building the genome regulatory network [95]. It was found that the human transcription factors establish a three-layered hierarchical network with the top (T) TFs regulating the lower orders of the network and coassociating with nc-RNAs and phosphorylome, the middle (M) TFs acting as the information-flow bottlenecks pipelining the communication between regulatory elements and the target genes, and the bottom (B) factors coupling with other "executive" TFs to change the state of expression of selected genes. This selectivity is controlled through a multilevel combinatorial and contextspecific mode differentiating at specific genetic loci and being highly variable in the context of proximal (the core promoter site) and distal (intergenic, chromatin-related regulation) interactions. These findings overlap with the gene regulatory networks analyzed in other organisms [103-106].

Transcription factors receive signaling from the cellular environment that stimulates either one cell, a group of cells, or the entire embryo region. The Spemann-Mangold organizer in amphibians, which gives rise to the central nervous system, is induced by the dorsalizing Nieuwkoop center located in the dorsalmost vegetal cells $[107,108]$. Formation of the Nieuwkoop center and the Spemann-Mangold organizer requires the maternal Wnt signaling. The organizer also needs the Wnt pathway to activate two key mesodermal transcription factors: siamois and twin [109]. These two proteins regulate the expression of an autoregulatory homeobox family transcription factor, Goosecoid, which directly controls the Spemann-Mangold organizer [110]. In this scenario, the goosecoid gene is the final target of a complex MIM regulatory network.

In the chicken embryo, Hensen's node is the analogous structure to the Nieuwkoop's center, which activates two sets of genes: the posterior marginal zone (PMZ) genes ( $V g 1$ and nodal) and the anterior border-setting genes (chordin and sonic hedgehog) [111]. Chordin and Nodal are the bone morphogenetic protein (BMP) antagonists that dorsalize ectoderm and mesoderm, but they are insufficient for the nervous system induction [112]. In this transcription factors network, the 
fibroblast growth signaling (FGF) pathway activates brachyury and tbx6 to specify the mesoderm cells and antagonize BMP [113]. These transcription factors also activate sip1 (intercellular mediator of the transforming growth factor- $\beta$ signaling) which prevents primitive streak cell ingression and allows the neural plate cells to remain in the epiblast.

These are only a few examples of how transcription factors operate in developing embryos. Together with morphogens, transcription factors constitute the spatiotemporal cues of the developing embryo in animals.

\section{Morphogens}

One of the greatest findings in developmental biology was presented by a mathematician. Alan Turing, in his 1952's Chemical Basis of Morphogenesis was the first to coin the term "morphogen" [114]. By definition, a morphogen is a biologically active substance with heterogeneous spatial distribution in a developmental field. This chemical substance fits the reaction-diffusion biological model which corresponds to the spatial and temporal changes of its concentration and further diffusion over a function of distance and time [115]. Morphogens occur in tissues in the forms of "waves" with a departure from equilibrium as an oscillatory drift; these oscillations are the temporally and spatially concentration gradients that organize different cell types in a defined spatial array (Figure 4).

According to the iconic French flag model, differential cellular responses elicited by a morphogen are the direct read-outs of different threshold levels of the morphogen which a given cell is exposed to [6]. Over the spatially distributed gradient of a morphogen, the low-threshold responders (cells) are activated by small doses of the morphogen, while the high-threshold responders need much higher concentrations of the same molecule [116]. These observations lead to formulating three main properties of biologically active morphogens. First, a morphogen must be distributed with a concentration gradient across a tissue (biological field). Second, it must act over great distances, not only through paracrine secretion. Finally, a morphogen must act directly on the cell and change expression of the genes [7].

The first discovered morphogen was Bicoid in Drosophila [117]. Bicoid determines the anterior pole of the fly's embryo by segmental distribution and interactions with other proteins; the anterior gradient is regulated through the very low affinity of the target cells - only high concentrations of Bicoid protein change the target cell's genes expression [118]. Several years after the identification of Bicoid, another morphogen was described in D. melanogaster, Decapentaplegic (dpp) [119]. This member of the Drosophila TGF- $\beta$ family defines the dorsalventral axis in the blastoderm and drives disparate cell lines' fates due to its concentration gradient [120]. To add to the complexity of how signaling pathways, morphogens and transcription factors dovetail on different molecular levels of all embryonic events, it was shown that the posterior pole cells (of the egg), which express a segment-polarity transcription factor Engrailed (en) that induce hedgehog expression; Engrailed acts here as a morphogen more than a protein of a signaling pathway. The hedgehog gradient finally instructs the neighboring cells to express dpp, tolloid, shrew, and screw, among others, which confine the dorsal part of the embryo while being repressed by the ventralizing factors such as dorsal and pipe [121, 122]. 


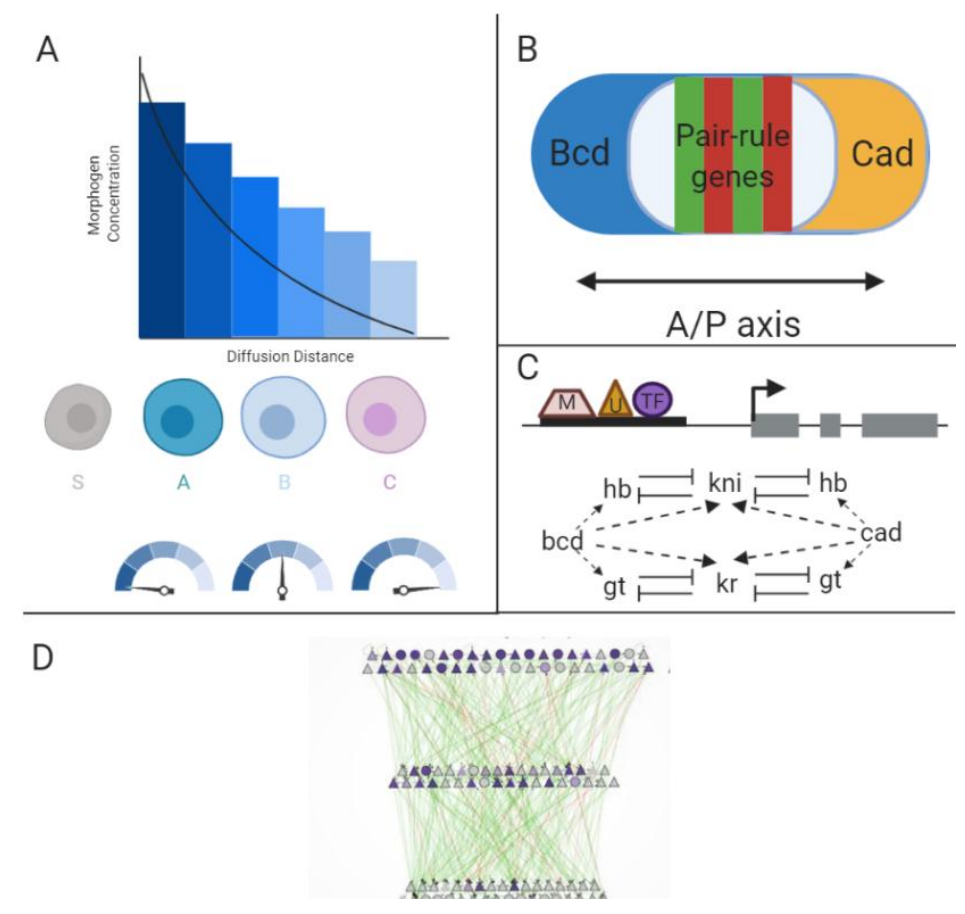

Figure 4 Morphogen gradient in a developing tissue and its biochemical activity toward the target transcription factors. (a) Long-range morphogens act in the gradient fashion by first regulating expression of the gene with the lowest affinity for that morphogen and regulating genes at further distances by a decrease in a morphogen's concentration. The differential response of cells to the morphogens gradients establishes differential genes patterning within the separate populations of cells which allows for the formation of developmental fields ( $S$, source cell; $A, B, C$, different cell types). (b) The anterior/posterior (A/P) axis establishment in $D$. melanogaster through the action of different morphogens forming their own gradient niches across the maturing oocyte. Bicoid (bcd) and Huntchback (hb) form the anterior gradient in the oocyte preventing the caudal mRNA expression in the anterior part of the egg and "pushing" it back, where Caudal establish the posterior pole. Pair-rule genes divide the embryo into seven transverse bands with equal distribution of determinants and body segments polarity, further formulating the A/P axis. (c) Modular regulation of target genes by morphogens and activated transcription factors network. Morphogen effectors (M) integrate the patterning signals by binding to specific cis-regulatory elements (CREs) in the DNA and to multiple TFs, including uniformly expressed factors $(U)$, regulatory factors, and repressors that comprise the morphogen-regulated transcriptional network. (d) Exemplary transcriptional network of DNA-binding and non-binding trans-regulatory elements and their intermodal hierarchical control (adapted from [95]).

Formation of the dorsoventral axis in Xenopus expresses the complexity of developmental field establishment and modeling. After the sperm entry, GSK3 is deactivated hence freeing $\beta$-catenin that accumulates in the dorsal portion of the amphibian embryo [124]. $\beta$-catenin and Tcf3 form a heterodimer that activates two transcription factors: Siamois and Twin. These two proteins interact with other transcription factors induced by TGF- $\beta$ family members, including Vg1, Activin 
and Brachyury, in order to upregulate the expression of a homeobox protein, Goosecoid [109, 125, 126]. Goosecoid is also a morphogen as it acts in the gradient manner and supports the organizer formation [127]. However, the BMP family members act counter to $\beta$-catenin, TGF- $\beta$ family members and Goosecoid by guiding the organizer's neighboring ectodermal cells to become the epidermis (instead of the default neural tube tissue). The organizer center responds be secreting the BMP inhibitors: noggin, chordin and follistatin [128]. It also represses the Wnt8 gene whose product ventralizes the amphibian embryo [129]. This example represents two significant features of the morphogen system: many signaling pathways act as morphogens and that inhibitors consistently produced by the neighboring cells form an opposing gradient repressing the antagonizing oscillatory wave [7, 123].

The complicated interplay between morphogens, signaling pathways and transcription factors allows for the precisely controlled mechanisms to navigate the formation and development of progenitor fields in the embryos. These mechanisms conclude in changing the cells' competence and what lineage they can differentiate into. Their state of lineage potency is usually determined by the fine balance between activation and repression of genes.

\section{Cellular Differentiation}

Differentiation is the final step in a cell's fate determination, where one cell lineage differentiates into another; this is the stage where the activity of morphogens, signaling pathways, and TFs conclude the cell fate determination. By the narrower definition, cellular differentiation is the committed and gradual change of the cell's potency into a specialized tissue cell which cannot differentiate any further (terminal differentiation). In order to develop into a specific cell lineage, the group of cells is first inducted by an external inducer that generates a concentration gradient of other inductive signals (the signaling cascade), which produces a sequence of differently induced cells. When this happens, these cells are specified, which means they are reversibly committed to develop into specific cell lineage and when additional extracellular signaling occurs (mostly through morphogens and direct intercellular communication), the specified cells commit irreversibly to their proper cell fate in the process of determination [130].

During the stage of specification, inducers make a given cell competent to respond to specific inductive signaling which either activates or deactivates a group of genes dedicated to only a few lineages. The best example is the mesodermal development in most vertebrates. Retinoic acid (RA) gradient in early mesodermal regions establishes the boundaries of Hoxb4, which subsequently makes the intermediate mesoderm cells competent to three paracrine transcription factors, Lim1, Pax2, and Pax8 which lead to the nephron tubules formation [131, 132].

One of the pioneering experiments in developmental biology that explain the mechanisms of early cell fate determination in animals was done on 8-cell tunicate embryos [133]. The yellow crescent cytoplasm was transferred from a B4.1 blastomere (developing further to endoderm and mesoderm, including skeletal myoblasts) to B4.2 cell (primarily fated as ectoderm), which induced it to develop into the skeletal muscle cell line. Competence prepares the cell to enter one of the given lineages, but a strong inducer can redefine the cell's specification and a cascade of determinants may lead to the ultimate differentiation. If the thoracic somite in a chick is transplanted to the cervical region, the animal will develop ribs in its neck [134]. This happens because the paraxial mesoderm cells are highly sensitive to the BMP gradients and the antagonists' 
(Activin, Noggin), but also to the FGF and Wnt signaling pathways [135, 136]; the combinatorial effects of Wnt/ $\beta$-catenin/FGF signaling opposing the high gradients of retinoic acid (RA) in the vertebrate somites is due to a molecular oscillator, the segmentation clock, which is another molecular rhythm device alike the one acting during the EGA that depends on the interplay between region-specific regulators and modifiers [137]. Henceforth, the introduction of the aforementioned thoracic somites to different morphogens and their gradients, signaling pathways, and paracrine factors specifies them and makes them develop into an entirely new cell line.

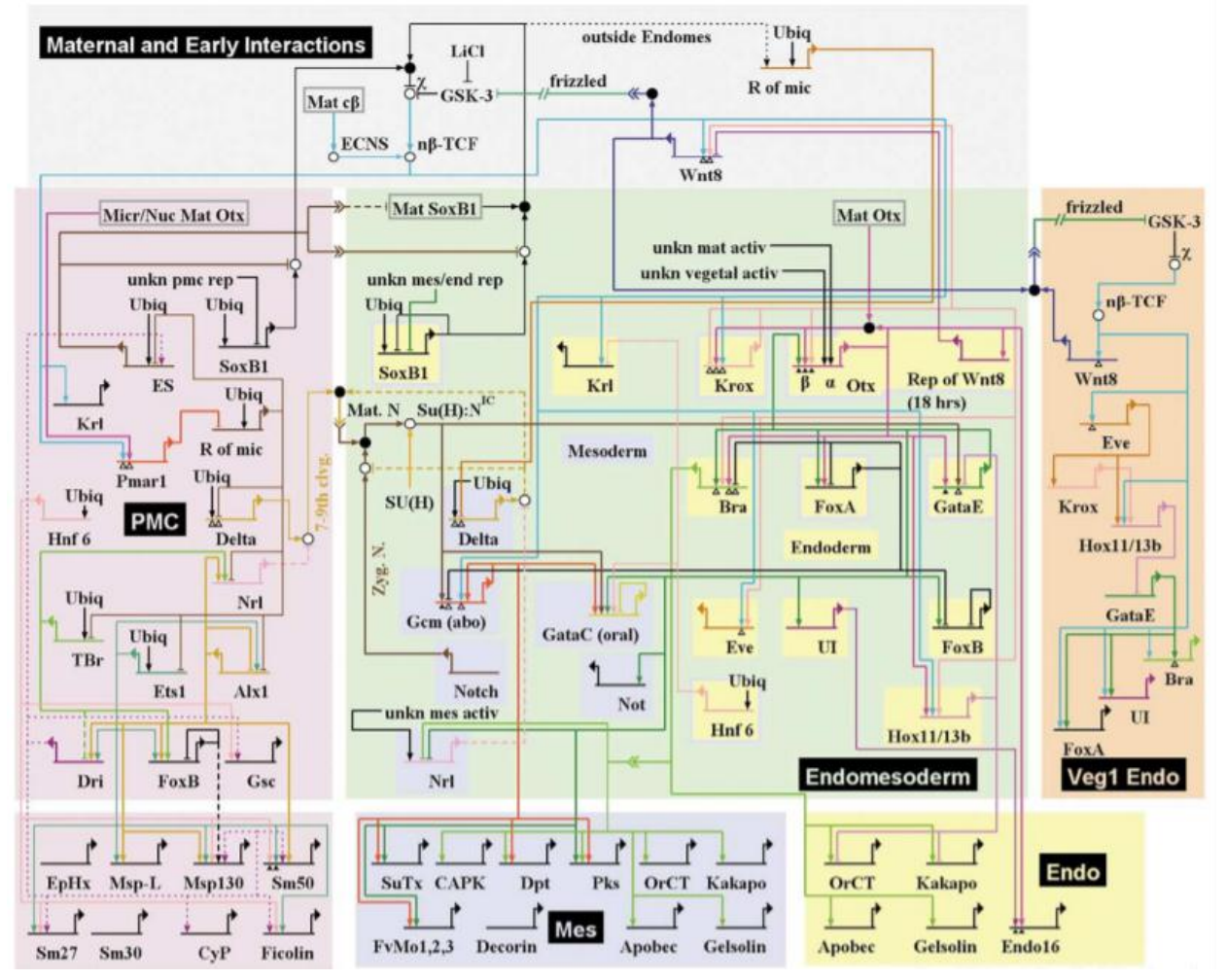

Figure 5 Exemplary gene regulatory network (GRN) of endomesoderm specification in sea urchin embryo. The interactions between cis- and trans-regulatory elements comprise the genetic modules or batteries controlled by specific binding sites of promoters and transcription factors changing the differential outcome of any given embryonic cell. The differential outcome varies at any given temporal and spatial configuration of the total set of transcription factors found at the differentiating cell. Each specified cell, in order to become fully determined into a tissue-specialized cell, must receive a distinct set of signals that will change its differentiating potential; this is achieved by the precise control of transcriptional network aggregated in separate circuits reciprocally affecting other circuits in a greater network of genetic regulation. Circuits compose the spatial domains (black boxes) which further build the bigger GRN that controls all embryonic events located in separate developmental fields. Short horizontal lines represent cis-regulatory elements; a bent arrow depicts transcription, while all the genes read at the bottom belong to the periphery of the GRN and are the ultimate target genes of higher (hierarchically) regulatory circuits. Black triangles represent the identified binding sites, while white triangles represent non-verified binding sites. Dotted lines indicate indirect relationships. Adapted from [96]. 
How do inducers change the fate of the cell on the genomic level? One of the finest approaches for explaining this phenomenon is seeing genes congregated as hardwired logical systems called batteries [76]. Each battery has a cis-regulatory module controlled by a very specific set of transacting modifiers (TFs). A node is a gene encoding one transcription factor and also having its own cis-regulatory module (sequence). Nodes cluster into batteries, and these construct the entire gene regulatory network (GRN) of an organism (Figure 5). By convention, repression is the dominant gene expression state, therefore inducers and trans-acting factors modulate the expression pattern of separate "batteries" of genes with a cumulative effect of changing the target cell's genomic identity. Ultimately, cells with similar lineage identity the make up the progenitor field, where the subcircuits of the GRN share the same clusters of transcription factors.

\section{Intercellular Communication during Embryogenesis}

The community effect is another course of action taken by the embryo cell through which the progenitor fields are established [138]. The competence for specification is also achieved through TF loops, chromatin remodeling, and autocrine synthesis of both a receptor and a ligand for signaling pathways, but it is the interblastomeric communication which maintains or changes the cell's differentiation state.

In Figure 6, the interactions between tissue A and tissue B can be either activating or inhibiting and these instructive interactions are carried by autocrine or juxtacrine (morphogens) signaling, or direct communication between cells in tissue $A$ and tissue $B$; if another sequence of cells is engaged (tissue $C$ ), the cumulative effect of all three signaling sources can be diverse and reshape this specific progenitor field. There is a marvelous number of such interactions that define the community effect.

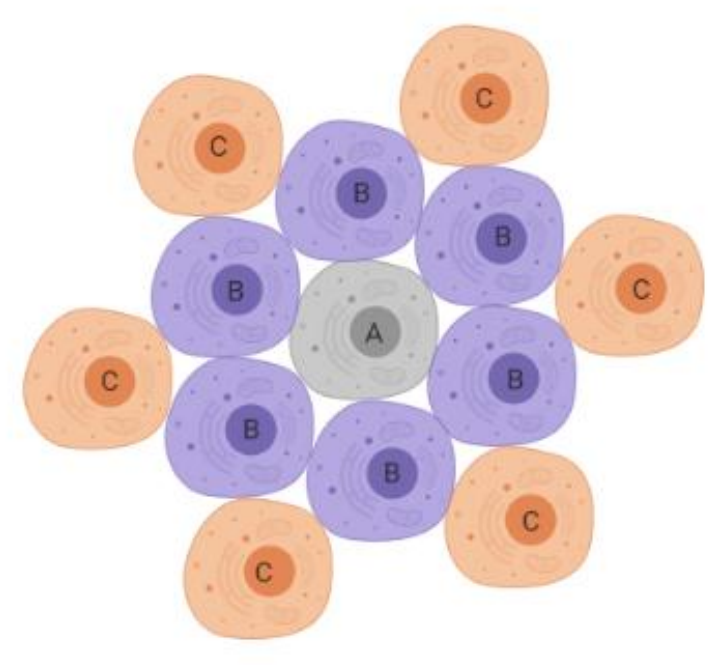

Figure 6 Community effect of blastomeres. Signaling is reciprocal and mixed, where the activation and inhibition inputs can affect the same cell and encode a combinatorial output. Interblastomeric communication is dynamic with the flow of differentiating information always adjusting to the nearby cell-to-cell communication and secreted signaling molecules diffusing over some distance of the cell community. 
The sea urchin veg 2 cells (second vegetal tier's cells) produce and secrete Wnt8 that affects only these cells. At the 60-cell stage embryo, Wnt8 is localized in all veg 2 tier cells [139]. The posterior and anterior cells in the Drosophila embryo synthesize two transcription factors crucial for intrasegmental patterning: Wingless and Engrailed; Engrailed is required to maintain the Wingless expression, which in turn activates the expression of Engrailed in the nearby cells [140]. The Nodal and Sh's co-play determines the left-right axis asymmetry in different animals where the right side cells express Activin, Fgf8, and Snail to block the synthesis of Shh and Pitx2; the left side depends on the Nodal/Hedgehog signaling which either inhibits the BMP signaling or snail expression or upregulates the synthetic activity in cells producing Cerberus, Lefty-1, and Pitx2 [141-143]. These are only a few examples of how intercellular communication is important to maintain or modify the changes of differentiation state in developing cells.

During embryogenesis two events occur interchangeably: the mesenchymal-epithelial transition (MET) and the epithelial-mesenchymal transition (EMT). MET is characterized by the cell's loss of motility, multipolar morphology and mesenchymal markers, such as N-cadherin, Twist, or fibronectin [144-146]. EMT is the reverse process, where mesenchymal cells gain all the features of epithelium, including gap junction, tight and adhere junctions, apico-basal polarity, and molecular markers such as E-cadherin, claudins, and connexins $[147,148]$. It is the mesenchymal's interactions with the extracellular matrix (ECM) and its proteins, and the epithelial cell-to-cell adhesion that largely drives embryogenesis in many animals. Many studies have tried to point at the earliest stage of the intercellular signaling occurrence and this matter has not yet been resolved. The research on $C_{x 43}$ gene, coding for connexin essential to the formation of gap junctions, showed that the gap junctional intercellular communication (GJIC) does not occur before the 8-cell stage mouse embryo [149]. In another study, blocking the $C_{x 43}$ expression in the pre-implantation mouse embryo led to downregulation of "stemness" factors (Nanog, ALP, Oct3/4) and drastic embryo development changes [150]. Those results demonstrated the opposite notion, where the GJIC does emerge at the very early embryonic stage.

Gap and tight junctions are only some of many examples how intercellular communication regulate cellular differentiation and establish numerous progenitor fields in the developing embryo. Direct determinants distribute between cells, juxtacrine and paracrine signaling through dissolved proteins, morphogens' gradients across different developmental fields, transcription factors looping - these mechanisms target chromatin and gene regulatory sequences that eventually concentrate on gene expression and the patterning of embryonic fields. Such mechanisms are observed in simple Volvox colonies and in the highly complex gene regulatory networks of human development [151].

\section{Embryogenesis Mechanisms - Human Perspective}

Humans share most embryological phenomena with other mammals which justifies the usage of experimental data from rodents, for instance, to explain the same molecular mechanisms in the human model. Major discrepancies occur in the earliest stages of cleavage and genome activation, and later during establishment of the specific developmental fields.

The human embryo represents the holoblastic rotational cleavage with equal distribution of yolk [29]. Humans are slow-developing animals with the EGA shift at the 4- to 8-cell embryo stage; however, there is a lack of consensus whether or not that human embryos depend on the 
maternal effect [152]. Like in mice, human embryos undergo pronuclear fusion, temporally distinct cleavage phases, compaction, and cavitation [37]. Moreover, both humans and mice exhibit stagespecific gene activation during the EGA phase [153]. However, the major genome activation (major EGA) with a dramatic reprogramming of gene expression in mice starts at the 2-cell stage [51], whereas, the major clearance of maternal determinants and independent embryo gene expression begins at the 4-cell stage in humans [154] (Figure 7). Zernicka-Goetz (1998) applied microsurgery to separate the animal and vegetal poles of the mouse zygote (meridional cut) and showed those eggs successfully developed into morulae and blastocysts indicating no physiological relevance of the spatial patterning (maternal effect) [155]. Similar experimental approach had been taken in the past generating analogous results [156]. On the other hand, Antczak \& van Blerkom (1997) had showed that leptin and STAT3, a cytokine and a signal transducer, are spatially polarized in mural and human oocytes proving the spatial patterning in mammals [157]. Recent data indicate that even slow-developing animals depend on the maternal determinants to some extent, including humans [158-160].

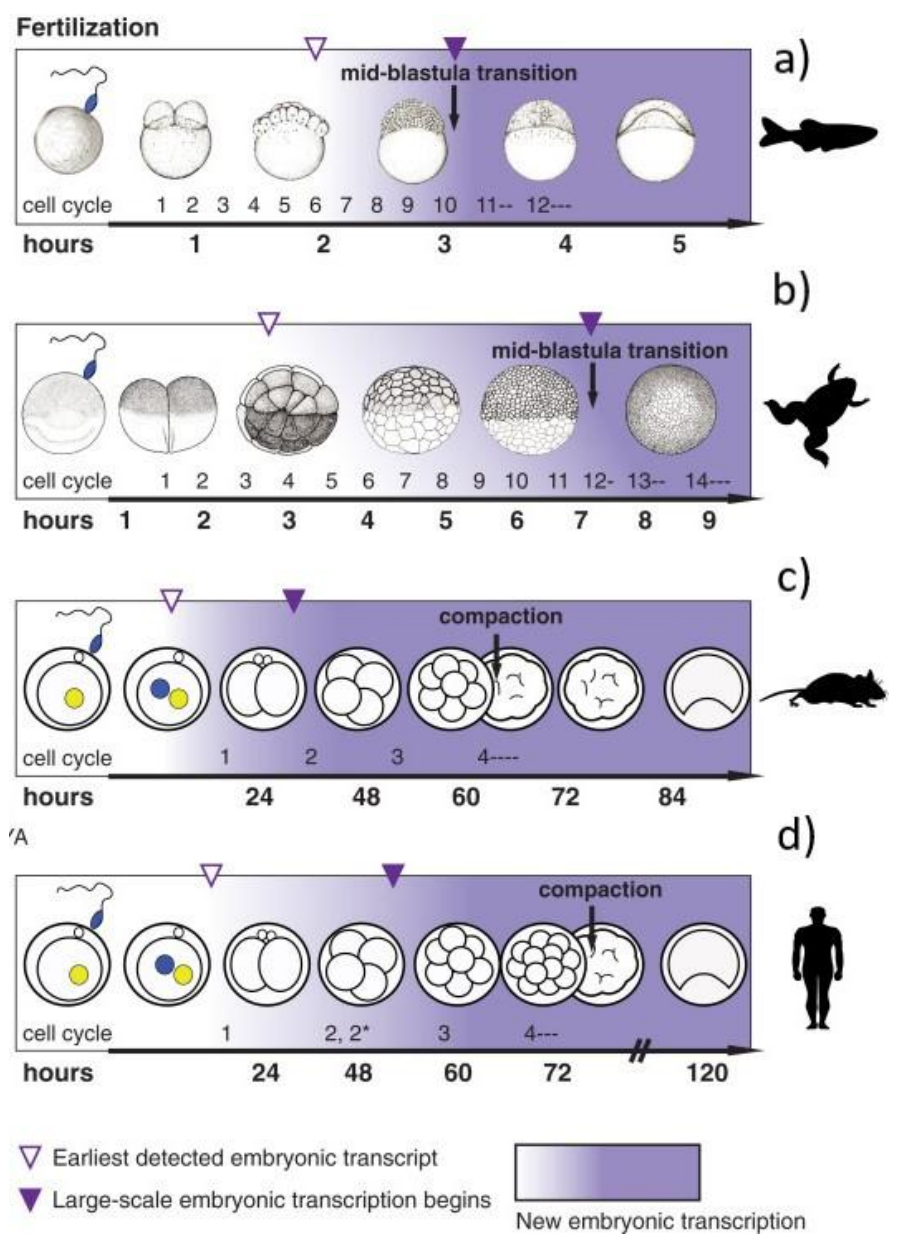

Figure 7 Early genome activation onset in fast- and slow-developing vertebrates. Fastdeveloping vertebrates $(a, b)$ exhibit rapid cell division following fertilization with late onset of the EGA event. Slow-developing mammals (c, d) are mostly independent from maternal determinants and hence start producing their mRNA transcripts much earlier in the pre-gastrulation stage of development. Divisions 2 and $2^{*}$ refer to the two asynchronous divisions in the second cleavage cycle. Adapted from [37]. 
Mammals represent the holoblastic, isolecithal cleavage with evenly distributed yolk with the first division being meridional (starting from the animal down to the vegetal pole) and the second being either meridional or equatorial [161]. In humans, the meridional cleavage generates two equally-sized cells, and the 2-cell embryo's cleavage furrow can produce four possible variants: one blastomere can divide meridionally and the other divides equatorially (ME variant), or the two blastomeres divide either through the equatorial ( $E$ variant) or the meridional furrow ( $M$ variant) [162]. During this time, the major genome reprogramming occurs, DNA methyltransferases catalyze de novo methylation patterning at CpG sites, methyl-CpG-binding proteins (MECPs) are inactivated, euchromatin is more abundant, and chromatin is found in the more relaxed state [163]. Morphogens act upon the early blastomeres through similar signaling pathways found in other vertebrates and invertebrates, activate the cascades of cellular signaling, and engage miscellaneous transcription factors to binding promoters and regulatory sites at the activated genes sites.

Most signaling pathways are conserved among animals during their development, however, some molecular and physiological differences count for the pathways' diversity and the scope of targets. For example, Drosophila codes 7 different genes belonging to the Wingless (Wnt) proteins family, whereas the human genome codes for as many as $19 \mathrm{Wnt}$ proteins [164]. Even though the mode of action is conserved, the variety and heterogeneity of the human signaling pathways and morphogens promote a higher differentiation in the developmental fields.

Fibroblast Growth Factor (FGF) signaling is conserved among all vertebrates [165]. FGF ligands act in numerous stages and tissues during embryonic development, including embryo implantation, A/V axis patterning, and neural induction [166-168]. FGF ligands, especially the highly dynamic FGF8, are expressed in the primitive streak and the neuromesodermal progenitors (NMP) region where some cells develop into the spinal cord and others become the paraxial mesoderm cells (developing into somites) $[169,170]$. FGFs are known as the "stemness" inducting factors promoting the NMP cells self-renewal and inhibiting their neural markers expression [171, 172]. However, it has been found that despite the conservation of FGF signaling in higher vertebrates, cell responses differ markedly between human and mouse in this instance. hESCs (human epiblast stem cells) have been recognized to respond to Nodal and Activin signaling by expressing Nanog; hESCs also act upon FGF2 induction, expressing Nanog and Oct4, whereas EpiSCs (mural epiblast stem cells) do not express FGF2. Thus, FGF signaling is limited early neurogenesis stage in mice [173].

Human developmental fields (progenitor fields) are formed as the resultants of the GRN acting through spatially and temporally well-defined waves of morphogens and signaling pathways that employ specific but overlapping sets of transcription factors modulating the gene batteries activity to hinder or support their expression profiles. Alike in other animals, human blastomeres communicate with each other to maintain tissue competence or change the state of their differentiation. Interblastomeric communication in humans is another developmental biology topic where the consensus has not been reached yet. In one study, tight and anchoring junctions have been shown to appear as early as at the 2- to 6-cell stage, while compared to the mural late junctions assembling occurring around the 8-cell stage [174]. Another study has shown that the electrical coupling (gap junctions) between early human blastomeres does not occur until the 8cell stage [175]. Those uncertainties leave much room for more profound and sophisticated research that one day would bring a definite answer to the question: What cellular and 
biochemical capacities allow for the formation of all human developmental fields derived from a single cell?

\section{Conclusion}

Since the emergence of multicellularity, which had occurred independently several times in the past, plants and animals have arisen employing different molecular tools to achieve the growing complexity of their tissues. Animals are the most complex multicellular eukaryotes on the planet; wisely adapting to the environment through tissue modification. Gene batteries and TF networks have consistently been evolving and increasing in complexity to help develop likewise complex and functional organs.

This is regulated through the well-tuned and synchronized cross-talk between soluble morphogens which induce the target cells' responses by concentration gradients and the highly conserved, yet species-specific signaling pathways regulating gene expression patterns through transcription factors. Even though some animals can be dependent on maternal constituents more than others, and hence go through the EGA later in the developmental process, every oocyte and every sperm cell contains embryological determinants that initiate first cascades of interconnected and often contradicting actions leading to axes formation, uneven gene regulators distribution, and interblastomeric connections establishment. Further molecular effects and developmental cues presence are aftermath of the organizing hierarchical structure of biochemical molecules.

However, none of those mechanisms, whether concerned separately or as a whole, explain how exactly a single cell, the zygote, gives rise to the unspeakable variety of cells across all multicellular organisms. No one can emphatically explain how the minute precision of morphogenesis is actually regulated and how the cellular cues control the cellular growth of every developmental niche. Why do the morphogenetic niches form in the first place and what evolutionary mechanisms have decided on employing specific genes orchestrating the complex intermodal networks and structural genes being orchestrated: developmental biology has not yet answered its major questions that had been asked since Aristotle.

However, the complexity of early developmental processes has been well studied, but many research results are contradicting and opposing to the already well-established facts which are taken for granted. Finding answers to the most frequently asked questions in developmental biology will one day bring this field closer to understanding the miracle of life.

\section{References}

1. Watson JD, Crick FHC. Molecular structure of nucleic acids: A structure for deoxyribose nucleic acid. Nature. 1953; 171: 737-738.

2. Morgan TH. What are "Factors" in Mendelian Explanations? Am Breed Assoc Rep. 1909; 5: 365-368.

3. Chen $X, X u H$, Yuan $P$, Fang $F$, Huss $M$, Vega VB, et al. Integration of external signaling pathways with the core transcriptional network in embryonic stem cells. Cell. 2008; 133: 1106-1117.

4. Zuber ME, Gestri G, Viczian AS, Barsacchi G, Harris WA. Specification of the vertebrate eye by a network of eye field transcription factors. Development. 2003; 130: 5155-5167. 
5. Carlsson $\mathrm{P}$, Margit $\mathrm{M}$. Forkhead transcription factors: key players in development and metabolism. Dev Biol. 2002; 250: 1-23.

6. Wolpert L. Positional information and the spatial pattern of cellular differentiation. J Theor Biol. 1969; 25: 1-47.

7. Gurdon JB, Bourillot PY. Morphogen gradient interpretation. Nature. 2001; 413: 797-803.

8. Denise N, Burke R, Struhl G, Basler K. Direct and long-range action of a DPP morphogen gradient. Cell. 1996; 85: 357-368.

9. Spemann $\mathrm{H}$, Mangold $\mathrm{H}$. Induction of embryonic primordia by implantation of organizers from a different species. 1923. Int J Dev Biol. 2003; 45: 13-38.

10. Davidson EH, Peterson KJ, Cameron RA. Origin of bilaterian body plans: Evolution of developmental regulatory mechanisms. Science. 1995; 270: 1319-1325.

11. Eisenbach M. Mammalian sperm chemotaxis and its association with capacitation. Dev Genet. 1999; 25: 87-94.

12. Ward GE, Brokaw CJ, Garbers DL, Vacquier VD. Chemotaxis of Arbacia punctulata spermatozoa to resact, a peptide from the egg jelly layer. J Cell Biol. 1985; 101: 2324-2329.

13. Vacquier VD, Moy GW. Isolation of bindin: the protein responsible for adhesion of sperm to sea urchin eggs. Proc Nat Acad Sci. 1977; 74: 2456-2460.

14. Kamei N, Glabe CG. The species-specific egg receptor for sea urchin sperm adhesion is EBR1, a novel ADAMTS protein. Genes Dev. 2003; 17: 2502-2507.

15. Kim KS, Cha MC, Gerton GL. Mouse sperm protein sp56 is a component of the acrosomal matrix. Biol Repr. 2001; 64: 36-43.

16. Zhu GZ, Myles DG, Primakoff P. Testase 1 (ADAM 24) a plasma membrane-anchored sperm protease implicated in sperm function during epididymal maturation or fertilization. J Cell Sci. 2001; 114: 1787-1794.

17. Loppin B, Dubruille R, Horard B. The intimate genetics of Drosophila fertilization. Open Biol. 2015; 5: 150076.

18. Phopin K, Nimlamool W, Lowe-Krentz LJ, Douglass EW, Taroni JN, Bean BS. Roles of mouse sperm-associated alpha-L-fucosidases in fertilization. Mol Repr Dev. 2013; 80: 273-285.

19. Venditti JJ, Donigan KA, Bean BS. Crypticity and functional distribution of the membrane associated $\alpha$-L-fucosidase of human sperm. Mol Repr Dev. 2007; 74: 758-766.

20. McCulloh DH, Chambers EL. Fusion of membranes during fertilization. Increases of the sea urchin egg's membrane capacitance and membrane conductance at the site of contact with the sperm. J Gen Physiol. 1992; 99:137-175.

21. Taylor CT, Lawrence YM, Kingsland CR, Biljan MM, Cuthbertson KSR. Fertilization and early embryology: Oscillations in intracellular free calcium induced by spermatozoa in human oocytes at fertilization. Hum Repr. 1993; 8: 2174-2179.

22. Wu GJ, Simerly C, Zoran SS, Funte LR, Schatten G. Microtubule and chromatin dynamics during fertilization and early development in rhesus monkeys, and regulation by intracellular calcium ions. Biol Repr. 1996; 55: 260-270.

23. Gallicano GI, McGaughey RW, Capco DG. Activation of protein kinase $C$ after fertilization is required for remodeling the mouse egg into the zygote. Mol Repr Dev. 1997; 46: 587-601.

24. Sharma D, Kinsey WH. PYK2: a calcium-sensitive protein tyrosine kinase activated in response to fertilization of the zebrafish oocyte. Dev Biol. 2013; 373: 130-140.

25. Newport J, Kirschner M. A major developmental transition in early Xenopus embryos: I. 
characterization and timing of cellular changes at the midblastula stage. Cell. 1982; 30: 675686.

26. Kane DA, Kimmel CB. The zebrafish midblastula transition. Development. 1993; 119: 447-456.

27. Smith ZD, Chan MM, Mikkelsen TS, Gu H, Gnirke A, Regev A, et al. A unique regulatory phase of DNA methylation in the early mammalian embryo. Nature. 2012; 484: 339-344.

28. Collazo A, Bolker JA, Keller R. A phylogenetic perspective on teleost gastrulation. Am Natur. 1994; 144: 133-152.

29. Hasley A, Chavez S, Danilchik M, Wuhr M, Pelegri F. Vertebrate embryonic cleavage pattern determination. Vertebr Dev. 2017; 953: 117-171.

30. Minc N, Burgess D, Chang F. Influence of cell geometry on division-plane positioning. Cell. 2011; 144: 414-426.

31. Singh D, Pohl C. Coupling of rotational cortical flow, asymmetric midbody positioning, and spindle rotation mediates dorsoventral axis formation in C. elegans. Dev Cell. 2014; 28: $253-$ 267.

32. Gönczy P, Rose LS. Asymmetric cell division and axis formation in the embryo. WormBook. 2005; 1: 1-20.

33. Piotrowska K, Zernicka-Goetz M. Role for sperm in spatial patterning of the early mouse embryo. Nature. 2001; 409: 517-521.

34. Gardner RL, Davies TJ. The basis and significance of pre-patterning in mammals. Philosophical Transactions of the Royal Society of London. Series B: Biological Sciences. 2003; 358: 13311339.

35. Hiiragi T, Solter D. First cleavage plane of the mouse egg is not predetermined but defined by the topology of the two apposing pronuclei. Nature. 2004; 430: 360-364.

36. Lee MT, Bonneau AR, Giraldez AJ. Zygotic genome activation during the maternal-to-zygotic transition. Ann Rev Cell Dev Biol. 2014; 30: 581-613.

37. Jukam DS, Shariati AM, Skotheim JM. Zygotic genome activation in vertebrates. Dev Cell. 2017; 42: 316-332.

38. Wei C, Salichos L, Wittgrove CM, Rokas A, Patton JG. Transcriptome-wide analysis of small RNA expression in early zebrafish development. Rna. 2012; 18: 915-929.

39. De Domenico E, Owens NDL, Grant IM, Gomes-Faria R, Gilchrist MJ. Molecular asymmetry in the 8-cell stage Xenopus tropicalis embryo described by single blastomere transcript sequencing. Dev Biol. 2015; 408: 252-268.

40. Merrill PT, Sweeton D, Wieschaus E. Requirements for autosomal gene activity during precellular stages of Drosophila melanogaster. Development. 1988; 104: 495-509.

41. De Renzis S, Elemento O, Tavazoie S, Wieschaus EF. Unmasking activation of the zygotic genome using chromosomal deletions in the Drosophila embryo. PLoS Biol. 2007; 5: e213.

42. Mayer W, Niveleau A, Walter J, Fundele R, Haaf T. Demethylation of the zygotic paternal genome. Nature. 2000; 403: 501-502.

43. Schier AF. The maternal-zygotic transition: Death and birth of RNAs. Science. 2007; 316: 406407.

44. Latham KE, Schultz RM. Embryonic genome activation. Front Biosci. 2001; 6: D748-D759.

45. Guven-Ozkan T, Nishi Y, Robertson SM, Lin R. Global transcriptional repression in C. elegans germline precursors by regulated sequestration of TAF-4. Cell. 2008; 35: 149-160. 
46. Van Hoof D, Muñoz J, Braam SR, Pinkse MWH, Linding R, Heck AJR, et al. Phosphorylation dynamics during early differentiation of human embryonic stem cells. Cell Stem Cell. 2009; 5: 214-226.

47. Hwang SY, Oh B, Füchtbauer A, Füchtbauer EM, Johnson KR, Solter D, et al. Maid: A maternally transcribed novel gene encoding a potential negative regulator of bHLH proteins in the mouse egg and zygote. Dev Dynam. 1998; 209: 217-226.

48. Dooley TP, Miranda M, Jones NC, DePamphilis ML. Transactivation of the adenovirus Ella promoter in the absence of adenovirus E1A protein is restricted to mouse oocytes and preimplantation embryos. Development. 1989; 107: 945-956.

49. Davis JrW, Schultz RM. Developmental change in TATA-box utilization during preimplantation mouse development. Dev Biol. 2000; 218: 275-283.

50. Nothias JY, Majumder S, Kaneko KJ, DePamphilis ML. Regulation of gene expression at the beginning of mammalian development. J Biol Chem. 1995; 270: 22077-22080.

51. Hamatani T, Garter MG, Sharov AA, Ko MSH. Dynamics of global gene expression changes during mouse preimplantation development. Dev Cell. 2004; 6: 117-131.

52. Newport J, Kirschner M. A major developmental transition in early Xenopus embryos: I. characterization and timing of cellular changes at the midblastula stage. Cell. 1982; 30: 675686.

53. Almouzni G, Wolffe AP. Constraints on transcriptional activator function contribute to transcriptional quiescence during early Xenopus embryogenesis. EMBO J. 1995; 14: 17521765.

54. Joseph SR, Palfy M, Hilbert L, Kumar M, Karschau J, Zaburdaev V, et al. Competition between histone and transcription factor binding regulates the onset of transcription in zebrafish embryos. Elife. 2017; 6: e23326.

55. Lee MT, Bonneau AR, Takacs CM, Bazzini AA, DiVito KR, Fleming ES, et al. Nanog, Pou5f1 and SoxB1 activate zygotic gene expression during the maternal-to-zygotic transition. Nature. 2013; 503: 360-364.

56. Fraser RA, Heard DJ, Adam S, Lavigne AC, Le Douarin B, Tora L, et al. The putative cofactor TIF1alpha is a protein kinase that is hyperphosphorylated upon interaction with liganded nuclear receptors. J Biol Chem. 1998; 273: 16199-16204.

57. Boyer LA, Lee TI, Cole MF, Johnstone SE, Levine SS, Zucker JP, et al. Core transcriptional regulatory circuitry in human embryonic stem cells. Cell. 2005; 122: 947-956.

58. Anderson KV, Nüsslein-Volhard C. Information for the dorsal-ventral pattern of the Drosophila embryo is stored as maternal mRNA. Nature. 1984; 311: 223-227.

59. Wood WB, Laufer JS, Strome S. Developmental determinants in embryos of caenorhabditis elegans. J Nematol. 1982; 14: 267-273.

60. Driever W, Nüsslein-Volhard C. A gradient of bicoid protein in Drosophila embryos. Cell. 1988; 54: 83-93.

61. Lehmann R, Nüsslein-Volhard C. The maternal gene nanos has a central role in posterior pattern formation of the Drosophila embryo. Development. 1991; 112: 679-691.

62. Struhl G, Johnston P, Lawrence PA. Control of drosophila body pattern by the hunchback morphogen gradient. Cell. 1992; 69: 237-249.

63. Kloc M, Bilinski S, Etkin LD. The Balbiani body and germ cell determinants: 150 years later. Curr Top Dev Bio. 2004; 59: 1-36. 
64. Dosch R, Wagner DS, Mintzer KA, Runke G, Wiemelt AP, Mullins MC. Maternal control of vertebrate development before the midblastula transition: Mutants from the zebrafish I. Dev cell. 2004; 6: 771-780.

65. Davidson EH. Spatial mechanisms of gene regulation in metazoan embryos. Development. 1991; 113: 1-26.

66. Moody SA, Bauer DV, Hainski AM, Huang S. 4 Determination of Xenopus cell lineage by maternal factors and cell interactions. Curr Top De Bio. 1996; 3: 2103-138.

67. Bally-Cuif L, Schatz WJ, Ho RK. Characterization of the zebrafish Orb/CPEB-related RNAbinding protein and localization of maternal components in the zebrafish oocyte. Mech Dev. 1998; 77: 31-47.

68. De Robertis EM, Larraín J, Oelgeschläger M, Wessely O. The establishment of Spemann's organizer and patterning of the vertebrate embryo. Nat Rev Genet. 2000; 1: 171-181.

69. Marlow FL. Maternal control of development in vertebrates: My mother made me do it! Morg Clayp Life Sci. 2010.

70. Edwards RG. Genetics of polarity in mammalian embryos. Reprod Biomed Online. 2005; 11: 104-114.

71. Piotrowska K, Zernicka-Goetz M. Role for sperm in spatial patterning of the early mouse embryo. Nature. 2001; 409: 517.

72. Gardner RL, Davies TJ. The basis and significance of pre-patterning in mammals. Philos Trans R Soc Lond B Biol Sci. 2003; 358: 1331-1339.

73. Tong ZB, Gold L, Pfeifer KE, Dorward H, Lee E, Bondy CA, et al. Mater, a maternal effect gene required for early embryonic development in mice. Nat Genet. 2000; 26: 267-268.

74. Wu X, Viveiros MM, Eppig JJ, Bai Y, Fitzpatrick SL, Matzuk MM. Zygote arrest 1 (Zar1) is a novel maternal-effect gene critical for the oocyte-to-embryo transition. Nat Genet. 2003; 33: 187-191.

75. Howell CY, Bestor TH, Ding F, Latham KE, Mertineit C., Trasler JM, et al. Genomic imprinting disrupted by a maternal effect mutation in the Dnmt1 gene. Cell. 2001; 104: 829-838

76. Davidson EH. The regulatory genome: Gene regulatory networks in development and evolution. Elsevier. San Diego: Academic; 2010.

77. Ingham PW. Pattern formation: Hedgehog points the way. Curr Biol. 1994; 4: 347-350.

78. Siegfried E, Perrimon N. Drosophila wingless: A paradigm for the function and mechanism of Wnt signaling. Bioessays. 1994; 16: 395-404.

79. Wall NA, Hogan BL. TGF- $\beta$ related genes in development. Curr Opin Genet Dev. 1994; 4: $517-$ 522.

80. Ingham PW, Nakano $\mathrm{Y}$, Seger $\mathrm{C}$. Mechanisms and functions of Hedgehog signalling across the metazoa. Nat Rev Genet. 2011; 12: 393-406.

81. Bürglin TR. Evolution of hedgehog and hedgehog-related genes, their origin from Hog proteins in ancestral eukaryotes and discovery of a novel Hint motif. BMC Genomics. 2008; 9: 127.

82. Buglino JA, Resh MD. Hhat is a palmitoylacyltransferase with specificity for N-palmitoylation of Sonic Hedgehog. J Biol Chem. 2008; 283: 22076-22088.

83. Mohler J, Vani K. Molecular organization and embryonic expression of the hedgehog gene involved in cell-cell communication in segmental patterning of Drosophila. Development. 1992; 115: 957-971. 
84. Price MA, Kalderon D. Proteolysis of the Hedgehog signaling effector Cubitus interruptus requires phosphorylation by Glycogen Synthase Kinase 3 and Casein Kinase 1. Cell. 2002; 108: 823-835.

85. Tempé $D$, Casas $M$, Karaz S, Blanchet-Tournier MF, Concordet JP. Multisite protein kinase A and glycogen synthase kinase $3 \beta$ phosphorylation leads to Gli3 ubiquitination by SCF $\beta \operatorname{TrCP}$. Mol Cell Biol. 2006; 26: 4316-4326.

86. Denef N, Neubüser D, Perez L, Cohen SM. Hedgehog induces opposite changes in turnover and subcellular localization of patched and smoothened. Cell. 2000; 102: 521-531.

87. Sisson JC, Ho KS, Suyama K, Scott MP. Costal2, a novel kinesin-related protein in the Hedgehog signaling pathway. Cell. 1997; 90: 235-245.

88. Ruel L, Rodriguez R, Gallet A, Lavenant-Staccini L, Thérond PP. Stability and association of Smoothened, Costal2 and Fused with Cubitus interruptus are regulated by Hedgehog. Nat Cell Biol. 2003; 5: 907-913.

89. Ohlmeyer JT, Kalderon D. Hedgehog stimulates maturation of Cubitus interruptus into a labile transcriptional activator. Nature. 1998; 396: 749-753.

90. Humke EW, Dorn KV, Milenkovic L, Scott MP, Rohatgi R. The output of Hedgehog signaling is controlled by the dynamic association between Suppressor of Fused and the Gli proteins. Genes Dev. 2010; 24: 670-682.

91. Pathi S, Pagan-Westphal S, Baker DP, Garber EA, Rayhorn P, Bumcrot D, et al. Comparative biological responses to human Sonic, Indian, and Desert hedgehog. Mech Dev. 2001; 106: 107-117.

92. Lee J, Platt KA, Censullo P, Altaba AR. Gli1 is a target of Sonic hedgehog that induces ventral neural tube development. Development. 1997; 124: 2537-2552.

93. St-Jacques B, Hammerschmidt M, McMahon AP. Indian hedgehog signaling regulates proliferation and differentiation of chondrocytes and is essential for bone formation. Genes Dev. 1999; 13: 2072-2086.

94. Bitgood MJ, Shen L, McMahon AP. Sertoli cell signaling by Desert hedgehog regulates the male germline. Curr Biol. 1996; 6: 298-304.

95. Gerstein MB, Kundaje A, Hariharan M, Landt SG, Yan KK, Cheng C, et al. Architecture of the human regulatory network derived from ENCODE data. Nature. 2012; 489: 91-100.

96. Oliveri $\mathrm{P}$, Davidson $\mathrm{EH}$. Gene regulatory network controlling embryonic specification in the sea urchin. Curr Opin Genet Dev. 2004; 14: 351-360.

97. Olson, Eric N. Gene regulatory networks in the evolution and development of the heart. Science. 2006; 313: 1922-1927.

98. Roeder RG. The complexities of eukaryotic transcription initiation: Regulation of preinitiation complex assembly. Trends Biochem Sci. 1991; 16: 402-408.

99. Gaszner M, Felsenfeld G. Insulators: Exploiting transcriptional and epigenetic mechanisms. Nat Rev Genet. 2006; 7: 703-713.

100. Ogbourne S, Antalis TM. Transcriptional control and the role of silencers in transcriptional regulation in eukaryotes. Biochem J. 1998; 331: 1-14.

101. Whyte WA, Orlando DA, Hnisz D, Abraham BJ, Lin CY, Kagey MH, et al. Master transcription factors and mediator establish super-enhancers at key cell identity genes. Cell. 2013; 153: 307-319.

102. Swiers G, Patient R, Loose M. Genetic regulatory networks programming hematopoietic stem 
cells and erythroid lineage specification. Dev Boil. 2006; 294: 525-540.

103. Ma HW, Buer J, Zeng AP. Hierarchical structure and modules in the Escherichia coli transcriptional regulatory network revealed by a new top-down approach. BMC Bioinformatics. 2004; 5: 199.

104. Milo R, Shen-Orr S, Itzkovitz S, Kashtan N, Chklovskii D, Alon U. Network motifs: simple building blocks of complex networks. Science. 2002; 298: 824-827.

105. Bhardwaj N, Kim PM, Gerstein MB. Rewiring of transcriptional regulatory networks: Hierarchy, rather than connectivity, better reflects the importance of regulators. Sci Sign. 2010; 3: ra79.

106. Gouti M, Delile J, Stamataki D, Wymeersch FJ, Huang Y, Kleinjung J, et al. A gene regulatory network balances neural and mesoderm specification during vertebrate trunk development. Dev Cell. 2017; 41: 243-261.

107. Nieuwkoop PD. The formation of the mesoderm in urodelean amphibians. Wilhelm Roux'Archiv für Entwicklungsmechanik der Organismen. 1969; 163: 298-315.

108. Vonica A, Gumbiner BM. The Xenopus Nieuwkoop center and Spemann-Mangold organizer share molecular components and a requirement for maternal Wnt activity. Dev Biol. 2007; 312: 90-102.

109. Moon RT, Kimelman D. From cortical rotation to organizer gene expression: toward a molecular explanation of axis specification in Xenopus. Bioessays. 1998; 20: 536-546.

110. Cho KWY, Blumberg B, Steinbeisser H, De Robertis EM. Molecular nature of Spemann's organizer: The role of the Xenopus homeobox gene goosecoid. Cell. 1991; 67: 1111.

111. Skromne I, Stern CD. A hierarchy of gene expression accompanying induction of the primitive streak by Vg1 in the chick embryo. Mech Dev. 2002; 114: 115-118.

112. Stern CD. Neural induction: old problem, new findings, yet more questions. Development. 2005; 132: 2007-2021.

113. Rubenstein JLR, Shimamura K, Martinez S, Puelles L. Regionalization of the prosencephalic neural plate. Ann Rev Neurosci. 1998; 21: 445-477.

114. Turing AM. The chemical basis of morphogenesis. Bull Math Biol. 1990; 52: 153-197.

115. Purwins HG, Bödeker HU, Liehr AW. Dissipative solitons in reaction-diffusion systems." Dissipative solitons. Springer, Berlin, Heidelberg, 2005. 267-308.

116. Tabata, Tetsuya, and Yuki Takei. "Morphogens, their identification and regulation. Development. 2004; 131: 703-712.

117. Nüsslein-Volhard C, Wieschaus E. Mutations affecting segment number and polarity in Drosophila. Nature. 1980; 287: 795

118. Driever $W$, Nüsslein-Volhard $C$. The bicoid protein is a positive regulator of hunchback transcription in the early Drosophila embryo. Nature. 1989; 337:138

119. Ferguson EL, Anderson KV. Decapentaplegic acts as a morphogen to organize dorsal-ventral pattern in the Drosophila embryo. Cell. 1992; 71:451-461.

120. Teleman AA, Cohen SM. Dpp gradient formation in the Drosophila wing imaginal disc. Cell. 2000; 103: 971-980.

121. Zecca M, Basler K, Struhl G. Sequential organizing activities of engrailed, hedgehog and decapentaplegic in the Drosophila wing. Development. 1995; 121: 2265-2278.

122. Moussian B, Roth S. Dorsoventral axis formation in the Drosophila embryo-shaping and transducing a morphogen gradient. Curr Biol. 2005; 15: R887-R899.

123. Lawrence PA. Morphogens: how big is the big picture? Nat Cell Biol. 2001; 3: E151-E154. 
124. Weaver C, Farr GH, Pan W, Rowning BA, Wang J, Mao J, et al. GBP binds kinesin light chain and translocates during cortical rotation in Xenopus eggs. Development. 2003; 130: 54255436.

125. Laurent MN, Blitz IL, Hashimoto C, Rothbacher U, Cho KW. The Xenopus homeobox gene twin mediates Wnt induction of goosecoid in establishment of Spemann's organizer. Development. 1997; 124: 4905-4916.

126. Vonica A, Gumbiner BM. Zygotic Wnt activity is required for Brachyury expression in the early Xenopus laevis embryo. Dev Biol. 2002; 250: 112-127.

127. Cho KWY, Blumberg B, Steinbeisser H, De Robertis EM. Molecular nature of Spemann's organizer: the role of the Xenopus homeobox gene goosecoid. Cell. 1991; 67: 1111.

128. Zimmerman LB, De Jesús-Escobar JM, Harland RM. The Spemann organizer signal noggin binds and inactivates bone morphogenetic protein 4. Cell. 1996; 86: 599-606.

129. Yao J, Kessler DS. Goosecoid promotes head organizer activity by direct repression of Xwnt8 in Spemann's organizer. Development. 2001; 128: 2975-2987.

130. Davidson EH. How embryos work: a comparative view of diverse modes of cell fate specification. Development. 1990; 108: 365-389.

131. Mauch TJ, Yang G, Wright M, Smith D, Schoenwolf GC. Signals from trunk paraxial mesoderm induce pronephros formation in chick intermediate mesoderm. Dev Biol. 2000; 220: 62-75.

132. Noon EPB, Barak H, Guttmann-Raviv N, Reshef R. Interplay between activin and Hox genes determines the formation of the kidney morphogenetic field. Development. 2009; 136: 19952004

133. Whittaker JR. Muscle lineage cytoplasm can change the developmental expression in epidermal lineage cells of ascidian embryos. Developmental biology 93.2 (1982): 463-470.

134. Kieny M, Mauger A, Sengel P. Early regionalization of the somitic mesoderm as studied by the development of the axial skeleton of the chick embryo. Dev Biol. 1972; 28: 142-161.

135. Pourquié O. Vertebrate somitogenesis. Ann Rev Cell Dev Biol. 2001; 17: 311-350.

136. Aulehla A, Pourquié O. Signaling gradients during paraxial mesoderm development. Cold Spring Harb Persp Biol. 2010; 2: a000869.

137. Pourquié 0 . The segmentation clock: converting embryonic time into spatial pattern. Sci. 2003; 301: 328-330.

138. Gurdon JB. A community effect in animal development. Nature. 1988; 336: 772-774.

139. Wikramanayake AH, Peterson R, Chen J, Huang L, Bince JM, McClay DR, et al. Nuclear $\beta$ catenin-dependent Wnt8 signaling in vegetal cells of the early sea urchin embryo regulates gastrulation and differentiation of endoderm and mesodermal cell lineages. Genesis. 2004; 39: 194-205.

140. Dougan S, DiNardo S. Drosophila wingless generates cell type diversity among engrailed expressing cells. Nature. 1992; 360: 347-350.

141. Raya A, Belmonte $\mathrm{JCl}$. Unveiling the establishment of left-right asymmetry in the chick embryo. Mech Dev. 2004; 121: 1043-1054.

142. Tabin CJ, Vogan KJ. A two-cilia model for vertebrate left-right axis specification. Genes Dev. 2003; 17: 1-6.

143. Marjoram L, Wright C. Rapid differential transport of Nodal and Lefty on sulfated proteoglycan-rich extracellular matrix regulates left-right asymmetry in Xenopus. Development. 2011; 138: 475-485. 
144. Yao D, Dai C, Peng S. Mechanism of the mesenchymal-epithelial transition and its relationship with metastatic tumor formation. Mol Canc Res. 2011; 9: 1608-1620.

145. Kang Y, Massagué J. Epithelial-mesenchymal transitions: twist in development and metastasis. Cell. 2004; 118: 277-279.

146. Gheld of A, Berx G. Cadherins and epithelial-to-mesenchymal transition. Progr Mol Biol Transl Sci. 2013; 116: 317-336.

147. Thiery JP. Epithelial-mesenchymal transitions in development and pathologies. Curr Opin Cell Biol. 2003; 15: 740-746.

148. Shook D, Keller R. Mechanisms, mechanics and function of epithelial-mesenchymal transitions in early development. Mech Dev. 2003; 120: 1351-1383.

149. Kidder GM, Winterhager E. Intercellular communication in preimplantation development: the role of gap junctions. Front Biosci. 2001; 6: D731-D736

150. Todorova MG, Soria B, Quesada I. Gap junctional intercellular communication is required to maintain embryonic stem cells in a non-differentiated and proliferative state. J Cell Physiol. 2008; 214: 354-362.

151. Prochnik SE, Umen J, Nedelcu AM, Hallmann A, Miller SM, Nishii I, et al. Genomic analysis of organismal complexity in the multicellular green alga Volvox carteri. Science. 2010; 329: 223226.

152. Dobson AT, Raja R, Abeyta MJ, Taylor T, Shen S, Haqq C, et al. The unique transcriptome through day 3 of human preimplantation development. Hum Mol Genet. 2004; 13: 1461-1470.

153. Xue Z, Huang K, Cai C, Cai L, Jiang C, Feng Y, et al. Genetic programs in human and mouse early embryos revealed by single-cell RNA sequencing. Nature. 2013; 500: 593-597.

154. Zhang P, Zucchelli M, Bruce S, Hambiliki F, Stavreus-Evers A, Levkov L, et al. Transcriptome profiling of human pre-implantation development. PloS One. 2009; 4.

155. Zernicka-Goetz M. Fertile offspring derived from mammalian eggs lacking either animal or vegetal poles. Development. 1998; 125: 4803-4808.

156. Tarkowski AK, Rossant J. Haploid mouse blastocysts developed from bisected zygotes. Nature. 1976; 259: 663-665.

157. Antczak M, Van Blerkom J. Oocyte influences on early development: The regulatory proteins leptin and STAT3 are polarized in mouse and human oocytes and differentially distributed within the cells of the preimplantation stage embryo. Mol Hum Repr. 1997; 3: 1067-1086.

158. Howell CY, Bestor TH, Ding F, Latham KE, Mertineit C, Trasler JM, et al. Genomic imprinting disrupted by a maternal effect mutation in the Dnmt1 gene. Cell. 2001; 104: 829-838.

159. Tong ZB, Bondy CA, Zhou J, Nelson LM. A human homologue of mouse Mater, a maternal effect gene essential for early embryonic development. Hum Repr. 2002; 17: 903-911.

160. Wu X, Viveiros MM, Eppig JJ, Bai Y, Fitzpatrick SL, Matzuk MM. Zygote arrest 1 (Zar1) is a novel maternal-effect gene critical for the oocyte-to-embryo transition. Nat Genet. 2003; 33: 187-191.

161. Gulyas BJ. A reexamination of cleavage patterns in eutherian mammalian eggs: Rotation of blastomere pairs during second cleavage in the rabbit. J Exp Zool. 1975; 193: 235-247.

162. Doronin YK, Senechkin IV, Hilkevich LV, Kurcer MA. Cleavage of human embryos: Options and diversity. Acta Nat. 2016; 8: 88.

163. Li E. Chromatin modification and epigenetic reprogramming in mammalian development. Nat Rev Genet. 2002; 3: 662-673. 
164. Logan CY, Nusse R. The Wnt signaling pathway in development and disease. Annu Rev Cell Dev Biol. 2004; 20: 781-810.

165. Golub R, Adelman Z, Clementi J, Weiss R, Bonasera J, Servetnick M. Evolutionarily conserved and divergent expression of members of the FGF receptor family among vertebrate embryos, as revealed by FGFR expression patterns in Xenopus. Dev Genes Evol. 2000; 210: 345-357.

166. Ornitz DM. FGF signaling in the developing endochondral skeleton. Cytok Growth Fact Revs. 2005; 16: 205-213.

167. Dailey L, Ambrosetti D, Mansukhani A, Basilico C. Mechanisms underlying differential responses to FGF signaling. Cytok Growth Fact Revs. 2005; 16: 233-247.

168. Diez del Corral R, Morales AV. The multiple roles of FGF signaling in the developing spinal cord. Front Cell Dev Biol. 2017; 5: 58.

169. Karabagli H, Karabagli P, Ladher RK, Schoenwolf GC. Comparison of the expression patterns of several fibroblast growth factors during chick gastrulation and neurulation. Anat Embryol. 2002; 205: 365-370.

170. Delfino-Machín M, Lunn JS, Breitkreuz DN, Akai J, Storey KG. Specification and maintenance of the spinal cord stem zone. Development. 2005; 132: 4273-4283.

171. Rash BG, Tomasi S, Lim HD, Suh CY, Vaccarino FM. Cortical gyrification induced by fibroblast growth factor 2 in the mouse brain. J Neurosci. 2013; 33: 10802-10814.

172. Maric D, Pla AF, Chang YH, Barker JL. Self-renewing and differentiating properties of cortical neural stem cells are selectively regulated by basic fibroblast growth factor (FGF) signaling via specific FGF receptors. J Neurosci. 2007; 27: 1836-1852.

173. Greber B, Wu G, Bernemann C, Joo JY, Han DW, Ko K, et al. Conserved and divergent roles of FGF signaling in mouse epiblast stem cells and human embryonic stem cells. Cell Stem Cell. 2010; 6: 215-226.

174. Dale B, Gualtieri R, Talevi R, Tosti E, Santella L, Elder K. Intercellular communication in the early human embryo. Mol Repr Dev. 1991; 29: 22-28.

175. Becker DL, Evans WH, Green CR, Warner A. Functional analysis of amino acid sequences in connexin43 involved in intercellular communication through gap junctions. J Cell Sci. 1995; 108: 1455-1467.

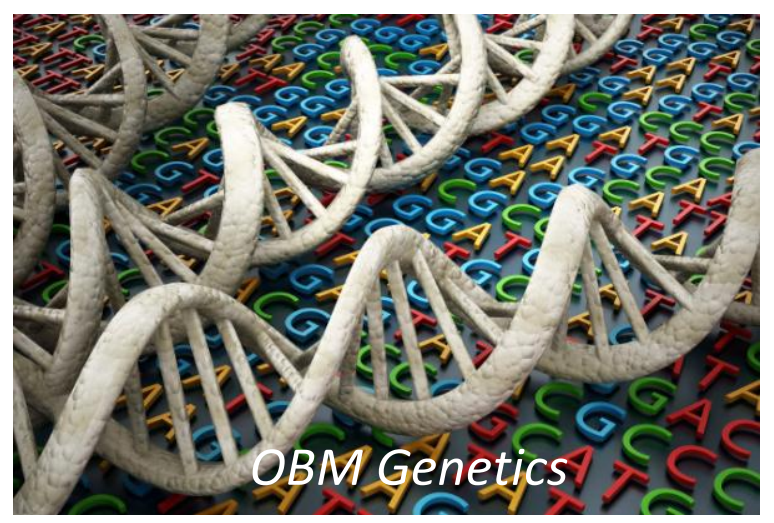

Enjoy OBM Genetics by:

1. Submitting a manuscript

2. Joining in volunteer reviewer bank

3. Joining Editorial Board

4. Guest editing a special issue

For more details, please visit: http://www.lidsen.com/journals/genetics 